\title{
FACTORS OF PHYSICAL DEVELOPMENT AND PHYSICAL EFFICIENCY OF STUDENTS FROM THE UNIVERSITY OF NATIONAL AND WORLD ECONOMY
}

\author{
Ekaterina Tosheva, Petko Mavrudiev \\ University of National and World Economy, Sofia, Bulgaria
}

\begin{abstract}
The aim of our research is to reveal the factor structure and to identify the main factors of the physical development and physical capacity of the studied population. Subject of the study are the factors of physical development and physical capacity of students. Object of the study are 41 student girls from UNWE.

The following research methods were used to solve the aim and tasks of the study: Theoretical analysis, anthropometry, sports-pedagogical testing, mathematical and statistical methods.

Six morpho-functional indicators were used to assess the physical development, including calculation of Body Mass Index (BMI). In order to determine the physical capacity of the students, 8 indicators were tested.

In order to process the results of the study, we used: Variable and Factor Analysis - To reveal the factor structure and to identify the main factors of physical development and physical capacity in the studied population. Correlation matrices are factorized by the main component method, followed by Varimax orthogonal rotation (Wainer, Braun, 1988).

The factor structure of the physical development and the physical capacity of the students studied by us from the University of National and World Economy is made up of 5 main factors, which in their entirety explain the high percentage of the initial variance of the studied phenomenon-76.51\%.
\end{abstract}

Key words: students, physical development, physical capacity, factor structure

\section{INTRODUCTION}

Physical education and sports in higher education system is seen as a subsystem of training, improving student health and preparation with the means of physical exercises and sports, and as an important factor for successful future professional realization. Improvement of this system is mainly associated with increasing the effectiveness of management of the educational process.

The role and importance of physical education and physical activity for the younger generation are incontestable. Above all, they neutralize hypodynamic to varying degrees and increase physical capacity. Enrichment of the motor skills (motor culture) of the person and the positive transfer of motor skills and habits with applied character, improve the health status and, respectively, positively influence the psycho-emotional state, professional realization and efficiency (Slanchev, 2014; Mavrudiev, 2018).

Physical development and physical capacity are important complex indicators that characterize the health status and reactivity of all age groups, in cluding students. Physical fitness is a very accurate and objective indicator that can be used to evaluate the effectiveness of training in physical education and sports, health status, and last but not least affect the future professional realization, which is why the search of the scientific community in these problems, especially in the context of the ever-increasing motor deficit of modern society, continue and do not lose their relevance. In our opinion, the identification of the main factors of physical development would help to improve the physical education process for students.

The use of factor analysis allows to determine the most important for each set of features, which are grouped in the so-called factors, reveal the priority sides of the factor structure of physical development and physical capacity, which is why it is extremely widely used in sports science, as in sportsmanship (Boshkova, 2007; Boshkova, Boshkov, 2017; Bonova, Labros, 2018; Borukova, 2018; Hristova, 2003; Tzarova, 2013) and physical education in the educational system (Mavrudieva, 2008; Mavrudieva et al, 2017; Borukova, 2019; Kasabova, 2011; Tzarova-Vasileva, 2012, 2017; Mavrudiev, 2018). 
The aim of our research is to discovery the factor structure and the identification of the main factors of physical development and the physical capacity of the studied population.

\section{METHODOLOGY}

The subject of research are the factors of physical development and physical capacity of students. Object of research are total of 41 female students from the UNWE.

The following research methods were used to solve the purpose and tasks of the research: Theoretical analysis, anthropometry, sports-pedagogical testing, mathematical-statistical methods.

6 morpho-functional indicators were used to assess physical development, including and the calculated (Index 4) Body Mass Index (BMI). To determine the physical fitness of students during the 2017/18 academic year, testing was performed on 8 indicators (Petkova, Kvartirnikova, 1985; Evrofit, 1992; Makenzi, 2011) (Table 1). In processing the results of the study, the following has been applied: Descriptive statistic and factor analysis - To discover the factor structure and identify the main factors of physical development and physical capacity in the population studied. Correlation matrices are factorized by the principal component method, followed by Varimax orthogonal rotation (Wainer, Braun, 1988; Gigova, 2002). The following criteria and parameters are taken into account when identifying and drawing the factors: Percentage of the variance of the studied phenomenon $\left(\alpha^{2}\right)$ explained by each factor; the degree of detection (manifestation) of the corresponding trait in the common factor structure, the information of which is given by the values of $h^{2}$; the factor weight of each indicator of a given factor and its direction (sign), which reveal the strength and nature of the relationship (positive or negative) between the indicators of the individual factor.

\section{RESULTS}

The results from the descriptive statistic of the observed indexes of physical fitness (Table 1 and Table 2) show that the values have a normal distribution, and the researched students are relatively homogeneous as regards the characteristics these indexes provide information for.

Table 1. Mean values and variability of the indexes of physical development of the UNWE students - women

\begin{tabular}{|l|l|l|l|l|l|l|l|l|}
\hline № & \multicolumn{1}{|c|}{ VARIABLES } & \multicolumn{1}{c}{ X } & \multicolumn{1}{c}{ S } & \multicolumn{1}{c|}{$\min$} & \multicolumn{1}{c|}{ max } & \multicolumn{1}{c|}{ As } & \multicolumn{1}{c|}{ Ex } \\
\hline 1. & Height & 167,98 & 6,57 & 3,91 & 155 & 179 & $-0,22$ & $-1,16$ \\
\hline 2. & Weight & 58,54 & 9,53 & 16,29 & 42 & 78 & 0,31 & $-0,67$ \\
\hline 3. & Body mass index (BMI) & 20,71 & 2,97 & 14,33 & 14,88 & 29,69 & 0,60 & 0,75 \\
\hline 4. & Chest circumference - respiratory difference & 6,61 & 1,73 & 26,18 & 3 & 10 & $-0,18$ & $-0,45$ \\
\hline 5. & Hand dynamometer - convenient & 23,95 & 5,64 & 23,54 & 11 & 38 & 0,18 & 0,04 \\
\hline 6. & Hand dynamometer - uncomfortable & 21,07 & 6,22 & 29,53 & 10 & 38 & 0,35 & 0,64 \\
\hline
\end{tabular}

Table 2. Mean values and variability of the indexes of physical fitness of the UNWE students - women

\begin{tabular}{|c|c|c|c|c|c|c|c|c|}
\hline № & VARIABLES & $\mathbf{X}$ & $\mathbf{S}$ & $\mathbf{V}$ & $\min$ & $\max$ & As & $\mathbf{E x}$ \\
\hline 7. & Sprint $20 \mathrm{~m}$ & 4.02 & 0.33 & 8.26 & 4.75 & 3.53 & 0.39 & -0.91 \\
\hline 8. & Shuttle $10 \times 5 \mathrm{~m}$ & 22.33 & 1.93 & 8.64 & 27 & 18.9 & 0.24 & -0.49 \\
\hline 9. & Long jump - from static position & 1.41 & 0.22 & 15.92 & 0.9 & 1.85 & -0.33 & -0.35 \\
\hline 10. & Throwing of tight ball - from sitting & 1.89 & 0.36 & 19.33 & 1.2 & 2.6 & 0.11 & -0.60 \\
\hline 11. & Throwing of tight ball - from lying & 1.58 & 0.48 & 30.32 & 0.7 & 2.9 & 0.38 & 0.10 \\
\hline 12. & Abdominal presses & 16.49 & 3.44 & 20.84 & 10 & 25 & 0.36 & -0.26 \\
\hline 13. & Flexibility & 101.90 & 6.27 & 6.15 & 91 & 118 & 0.44 & 0.14 \\
\hline 14. & Flamingo & 2.88 & 2.18 & 75.80 & 7 & 0 & 0.50 & -0.77 \\
\hline
\end{tabular}

For the purposes of the study, we applied factor factor loading. It can be identified as' the speed and analysis. The first factor (Figure 1) explains 20.69\% the explosive power of the lower limbs, which are and is determined by 4 major items that have high positively affected by equilibrium stability. 
Table 3. Factor structure of physical development and physical capacity of UNWE students - women

\begin{tabular}{|l|l|l|l|l|l|l|l|l|}
\hline \multicolumn{1}{|c|}{ № } & \multicolumn{1}{|c|}{ Parameters } & \multicolumn{1}{|c|}{ I } & \multicolumn{1}{|c|}{ II } & \multicolumn{1}{|c|}{ IV } & \multicolumn{1}{|c|}{$\mathbf{V}$} & \multicolumn{1}{c|}{$\mathbf{h}^{\mathbf{2}}$} & $\mathbf{1}-\mathbf{h}^{\mathbf{2}}$ \\
\hline 1. & Height & 0,070 & 0,401 & $-0,092$ & 0,729 & 0,187 & 0,741 & 0,259 \\
\hline 2. & Weight & 0,312 & 0,885 & 0,068 & 0,045 & 0,164 & 0,914 & 0,086 \\
\hline 3. & Body mass index (BMI) & 0,319 & 0,795 & 0,114 & $-0,344$ & 0,065 & 0,870 & 0,130 \\
\hline 4. & $\begin{array}{l}\text { Chest circumference - respiratory } \\
\text { difference }\end{array}$ & $-0,208$ & 0,018 & 0,094 & 0,005 & 0,832 & 0,744 & 0,256 \\
\hline 5. & Hand dynamometer - convenient & $-0,129$ & 0,114 & 0,902 & 0,090 & 0,135 & 0,870 & 0,130 \\
\hline 6. & Hand dynamometer - uncomfortable & $-0,191$ & 0,079 & 0,922 & 0,071 & 0,181 & 0,930 & 0,070 \\
\hline 7. & Sprint 20 m & 0,869 & 0,043 & $-0,159$ & $-0,051$ & $-0,221$ & 0,834 & 0,166 \\
\hline 8. & Shuttle 10 x 5 m & 0,814 & $-0,074$ & $-0,127$ & $-0,145$ & $-0,226$ & 0,757 & 0,243 \\
\hline 9. & Long jump - from static position & $-0,824$ & $-0,182$ & 0,102 & 0,133 & 0,012 & 0,740 & 0,260 \\
\hline 10. & Throwing of tight ball - from sitting & $-0,178$ & 0,782 & 0,187 & 0,274 & $-0,031$ & 0,754 & 0,246 \\
\hline 11. & Throwing of tight ball - from lying & $-0,352$ & 0,691 & $-0,173$ & 0,246 & $-0,302$ & 0,784 & 0,216 \\
\hline 12. & Abdominal presses & $-0,100$ & $-0,072$ & 0,199 & 0,755 & $-0,106$ & 0,636 & 0,364 \\
\hline 13. & Flexibility & $-0,143$ & $-0,013$ & 0,724 & $-0,013$ & $-0,467$ & 0,762 & 0,238 \\
\hline 14. & Flamingo & 0,559 & $-0,001$ & $-0,101$ & 0,165 & 0,152 & 0,373 & 0,627 \\
\hline$\Sigma \alpha$ & & 20,69 & 19,51 & 17,07 & 10,29 & 8,95 & $76,51 \%$ & \\
\hline
\end{tabular}

The first factor (Figure 1) explains $20.69 \%$ and is explosive power of the lower limbs, which are posidetermined by 4 major items that have high factor tively affected by equilibrium stability. loading. It can be identified as' the speed and the

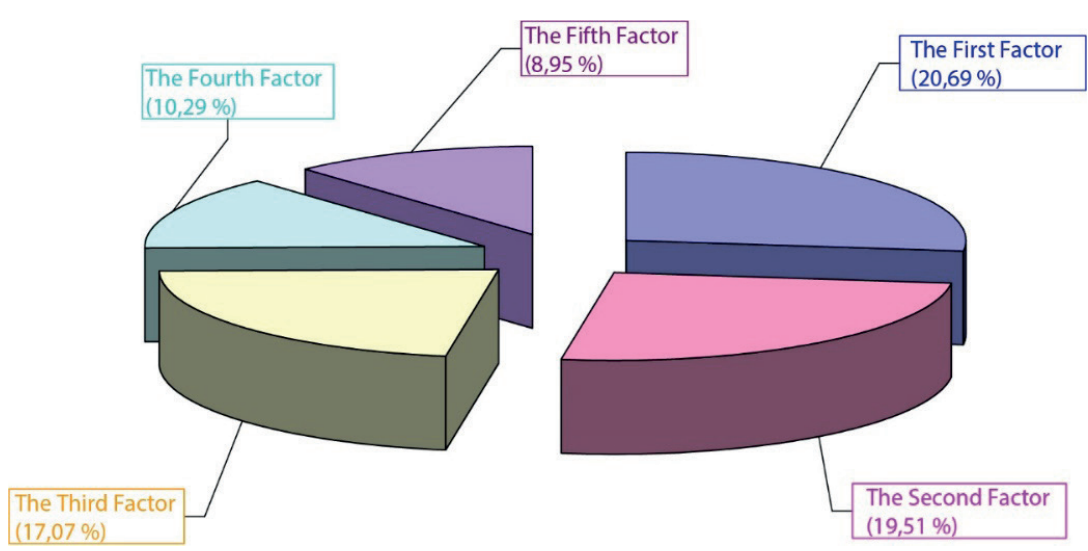

Figure 1. Relative proportions of the explained from the deductive factor's initial variance of the physical development and physical capacity of the students of UNWE - women

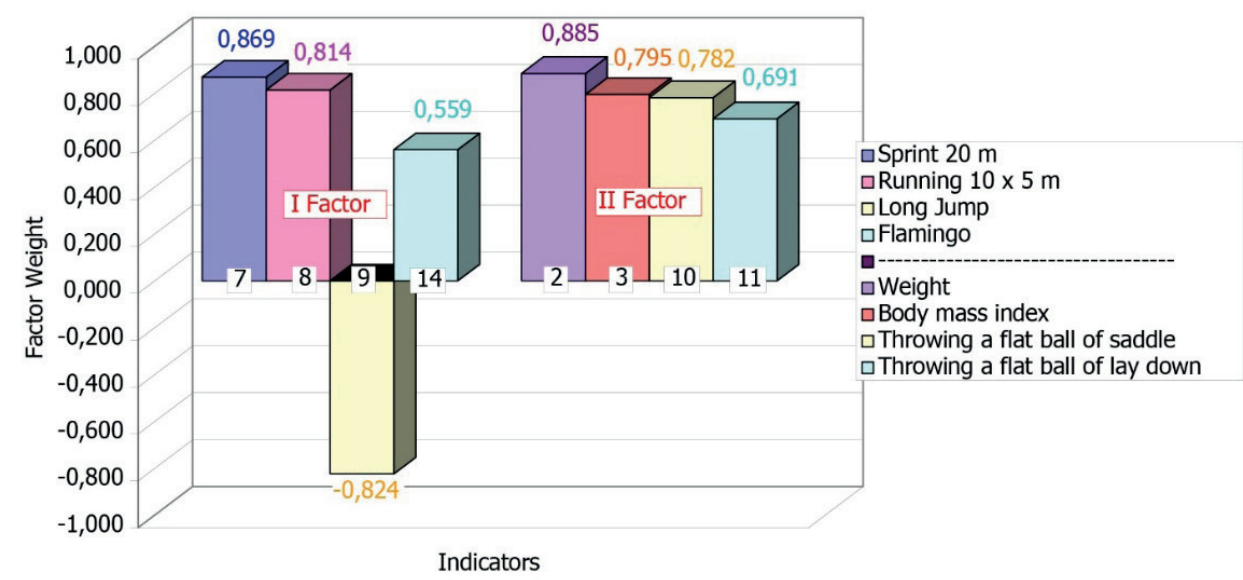

Figure 2. Factor structure of the physical development and physical capacity of the UNWE women students - I and II factors 
The second factor (19.51\%) revealed the importance of body mass and its relationship with the manifestations of the explosive force of the upper limbs (fig. 2).

The third factor (17.07\%) is largely a morphofunc- tional factor. Determines the place in the factor structure of physical development and the physical capacity of the static force of the upper limbs (indicators 5 and 6 - factor loadings 0,902 and 0,922 ) and the flexibility of the body (indicator 13 - factor loading 0.724) - Figure 3.

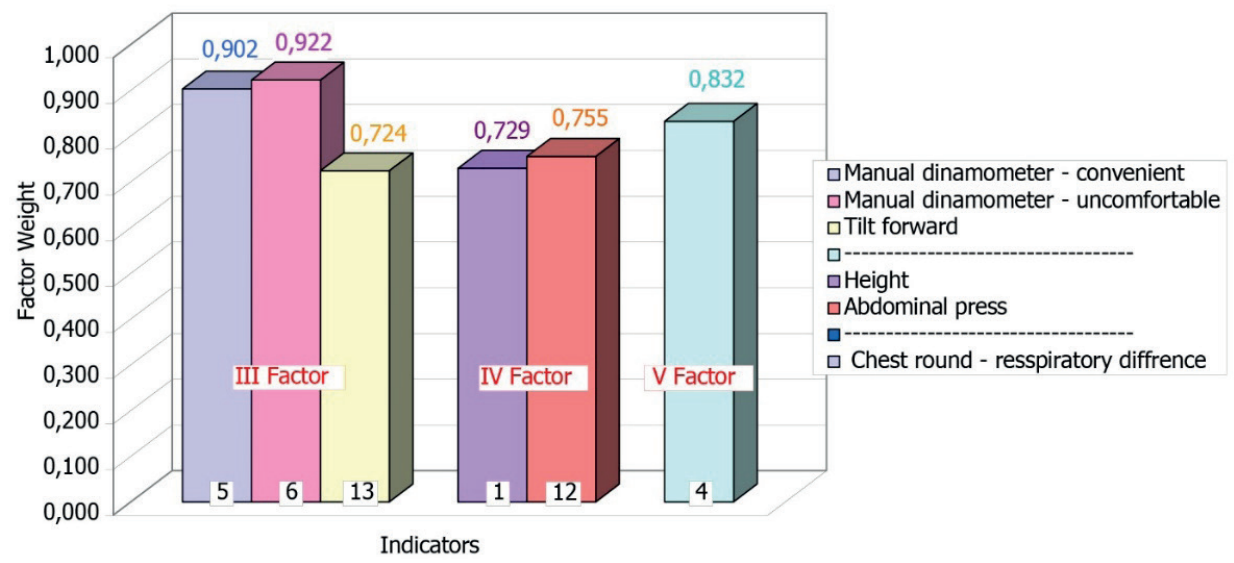

Figure 3. Factor structure of the physical development and physical capacity of the UNWE women students - III, IV and V factors

The fourth factor (10.29\%) has high factor loading in it by two of the studied traits - No. 12 (abdominal presses - factor weight 0.755 ) and No. 1 (height factor loading 0.729 ). The factor can be identified as "the explosive force of the abdominal muscles, which is positively correlated with the height of future economists" (Figure 3).

The fifth factor (8.95\%) revealed the contribution to the factor structure of physical development and the physical capacity of the functional capacity of the chest (Figure 3).

\section{CONCLUSIONS}

The factor structure of the physical development and the physical capacity of the students studied by us from the University of National and World Economy is made up of 5 main factors, which in their entirety explain the high percentage of the initial variance of the studied phenomenon - 76.51\%.

The first factor explains $20.69 \%$ and is defined by 4 major items that have high factor loadings and identifies as "the speed and explosive power of the lower limbs, which are positively affected by their equilibrium stability".

The second factor (19.51\%) revealed the importance of body weight and its relationship with the manifestations of the explosive power of the upper limbs. The third factor (17.07\%) is largely a morphofun- ctional factor. Determines the place in the factor structure of the physical development and the physical capacity of the static force of the upper limbs and the flexibility of the body.

The fourth factor (10.29\%) can be identified as "the explosive force of abdominal muscles that is positively correlated with the height of future economists".

The fifth factor (8.95\%) reveals the contribution to the factor structure of physical development and the physical capacity of the functional capacity of the chest.

\section{REFERENCES}

Bojkova, A. (2007). Korelacionno-struktorni modeli na skorostno-siloite kachestva pri voleibolisti. $S b . " N a-$ cionalna sisigurnost, fizicheska podgotovka I sport, s.161-169. V. Tarnovo, Izdatelstvo "Faber". // Божкова, А. (2007). Корелационно-структурни модели на скоростно-силовите качества при волейболисти. Сб. „Национална сигурност, физическа подготовка и спорт”, с. 161-169, В. Търново, Издателство „Фабер“. Bonova, I., Labros, P. (2018). Faktori na specifichnata sportna rabotosposobnost $\mathrm{v}$ byagametp ma sredni razstoyania za yunoshi vav vuzrastta 15-19 godini “Sport I nauka". Broy 6/2018, pp. 38-49 // Бонова, И., Лаброс, Р. (2018). Фактори на специфичната спортна работоспособност в бягането на средни разстояния за юноши във възрастта 15-19 години "Сnорm u 
наука". Брой 6/2018, стр. 38-49.

Borukova, M. (2018). Upravlenie i control na sportnata podgotovka pri 13-14 godishni basketbolistki. Sofia, Bolid ins. // Борукова, М., (2018). Управление и контрол на спортната подготовка при 13-14 годишни баскетболистки. София, Болид-инс

Borukova, M. (2019). Factor structure and major factors of physical ability of 13-14-year-old pupils, Journal of Applied Sports Sciences 2019, Vol.1, pp. 77 - 84. ISSN 2534-9597 (Print), ISSN 2535-0145 (Online)

Boshkov, G., A. (2017). Bozhkova Factor structure of physical and technical-tactic preparedness with highly-qualified female basketball players. International Journal of Physical Education, Sports and Health, Volume 4, Issue 1, Part C, pp. 125-130, 2017.

Brian Mackenzie, (2011). 101 testa za ocenka na fizicheskata godnost, BINS, str. 27, prevod D. Stefanova // Браян Маккензи, (2011). 101 теста за оценка на физическата годност, БИНС, стр.27, превод Д. Стефанова.

Evrofit Evropeyski testove za fizicheska godnost. (1992). Komitet za razvitie na sporta pri Suveta na Evropa, // Еврофит Европейски тестове за физическа годност. (1992). Комитет за развитие на спорта при Съвета на Европа.

Gigova, V. (2002). Statisticheska obrabotka I analiz na Danni, Sofia, NSA-IPB. // Гигова, B. (2002). Статистическа обработка и анализ на данни. София, НСА ИПБ.

Hristova, V. (2003). Faktorna struktura na zashtitnata igra vuv voleybola, FIS KOMUNIKACIJE, Nish, pp. 162166 // Христова, В. (2003). Факторна структура на защитната игра във волейбола, FIS KOMUNIKACIJE, Ниш, 2003, с. 162-166.

Kasabova, L. (2011). Vliyanie na igrata basketbol vurhu fizicheskata deesposobnost pri studentki ot UNSS, Sbornik "Suvremenni tendencii, problem I inovacii vav fizicheskoto vuzpitanie I sport vav Visshite uchilishta", S., "Stopanstvo" UNSSm pp. 250-256, ISBN 978-954-644223-9-УИ // Касабова, Л. (2011). Влияние на играта баскетбол върху физическата дееспособност при студентки от УНСС, Сборник „Съвременни тенденции, проблеми и иновации във физическото възпитание и спорт във Висшите училища“, С., 2011 „Стопанство“ УНСС, с. 250 - 256, ISBN 978-954-644223-9-УИ

Mavrudiev, P. (2018). Fizichesko razvitie I deesposobnost na student, Dis. Sofiiski Universitet "Sv. Kliment Ohridski”, S. // Маврудиев, П. (2018). Физическо развитие и дееспособност на студенти, Дис. Софийски университет „Св. Климент Охридски „, С.
Mavrudieva, N. (2008). Factorna struktura na fizicheskata godnost I sportno-tehnicheskite umenia na uchenitzi ot VI klas na SOU. Sport \& nauka, Izvanreden broi 4, pp. 172-183). // Маврудиева, Н. (2008). Факторна структура на физическата годност и спортнотехническите умения на ученици от VI клас на СОУ. “Спорт и наука". Извънр. Брой 4/2008, с. 173-183.

Mavrudieva, N., Iskrov, V., Tzarova-Vasileva, A. (2015). Fizicheskoto razvitie na uchenici, uchastvashti v izvunurochni zanimania po basketbol. VTU, "Faber", V. Turnovo, , ISBN: 978-619-00-0352-6, str. 518-524 // Маврудиева, Н., Искров, В., Църова - Василева, А. (2015). Физическо развитие на ученици, участващи в извънурочни занимания по баскетбол. ВТУ, “Фабер”, В. Търново, 2015, ISBN: 978-619-00-0352-6, стр. 518-524.

Petkova, L., Kvartirnikova, M. (1985). Testove za ozenjavane na fizicheskata deesposob-nost. Sofia, Medicina \& Fizkultura. // Петкова, Л., Квартирникова, М. (1985). Тестове за оценяване физическата дееспособност. София, Медицина и Физкултура

Slanchev, P. (2014). Sportna medicina: Uchebnik za student ot NSA. Sofia, Novi znania. ISBN 978-954-2907-541 // Слънчев, П. (2014). Спортна медицина: Учебник за студенти от НСА, Нови знания, София, ISBN 978954-2907-54-1.

Tsarova-Vasileva, A. (2012). Izsledvane na fizicheskoto razvitie I deesposobnostta na student ot grupite po basketbol na TU (Sofia), Sport \& Nauka, Izv. Broy 5, Sofia, ISSN: 1310-3393, pp. 64-70 // Църова-Василева, А. (2012). Изследване на физическото развитие и дееспособността на студенти от групите по баскетбол на ТУ (София). Спорт \& Наука, Изв. брой 5, София, 2012, ISSN: 1310-3393, стр. 64-70.

Tsarova-Vasileva, A. (2019). Basketbolut vav visshite uchilishta $v$ Bulgaria. Monografichen trud, Vtoro preraboteno I dopulneno izdanie, Sofia, BOLIT-INS ISBN 978-954-394-245-9 // Църова-Василева, А. (2019). Баскетбольт във висшите училищза в България. Монографичен труд, Второ преработено и допълнено издание, София, БОЛИТ-ИНС, ISBN 978-954-394-245-9

Tzarova, R. (2013). Problemi na kontrola $v$ basketbola, Sofia, Bolid ins. // Църова, Р. (2013). Проблеми на контрола в баскетбола. София. Болид инс.

\section{Corresponding authors: Ekaterina Tosheva, PhD} Sport department, University of National and World Economy E-mail: katia_to6eva@abv.bg 